\title{
Dukungan Sosial pada Anak dengan Autisme dari Orang Tua yang Memiliki Lembaga Pendidikan dan Pelayanan Anak Berkebutuhan Khusus (ABK)
}

\author{
Syamya Noor Hasanah, Irfan Noor dan Shanty Komalasari \\ Universitas Islam Negeri (UIN) Antasari Banjarmasin
}

\begin{abstract}
Autism is a developmental disorder that result in a children growth does not develop optimally, both in terms of communication, social interaction motor, sensory and emotion, so that children needs social support from people around them, especially parents in doing daily activities. Social support is divided into four type, that is emotional support, esteem support, tangible or instrumental support, and informational support. Type of research using case study with a qualitative approach. The research subject were father and mother who have autism children and have services for children with special needs. Data collection techniques using observation, interview, and documentation. Data analysis techniques using data collection techniques, data reduction data presentation and drawing conclusions. The results show that the social support which is given by parents including emotional support in the form of affection, care and concern, listening and trusting, then esteem support in the form giving reward for positive things done by children, informational support in the form of finding out and giving information that the children needs, tangible or instrumental support in the form of providing materials and facilities, provides job assistance or services and spending time.
\end{abstract}

Keywords: Social support; autism; parents have educational institution and services for children with special needs

\begin{abstract}
Abstrak
Autisme merupakan gangguan perkembangan yang mengakibatkan pertumbuhan anak tidak berkembang dengan optimal, baik dari segi komunikasi, interaksi sosial, motorik, sensori dan emosi, sehingga anak dengan autisme memerlukan dukungan sosial dari orang disekitarnya, terutama orang tua dalam melakukan aktifitas sehari-hari. Dukungan sosial terbagi menjadi empat, yaitu dukungan emosional, dukungan penghargaan, dukungan instrumental dan dukungan informasi. Jenis penelitian menggunakan penelitian studi kasus dengan pendekatan kualitatif. Subjek penelitian adalah ayah dan ibu yang memiliki anak dengan autisme dan mempunyai lembaga pendidikan dan pelayanan anak berkebutuhan khusus (ABK). Teknik pengumpulan data yaitu observasi, wawancara dan dokumentasi. Teknik analisis data menggunakan teknik pengumpulan data, reduksi data, penyajian data dan penarikan kesimpulan. Hasil penelitian menunjukkan bahwa dukungan sosial yang diberikan orang tua yaitu meliputi dukungan emosional yang berupa kasih sayang, peduli dan perhatian, mendengarkan serta kepercayaan, kemudian dukungan penghargaan berupa memberikan reward atas hal positif yang dilakukan anak, dukungan instrumental berupa memberikan meteri atau fasilitas, memberikan bantuan pekerjaan atau jasa serta meluangkan waktu dan dukungan
\end{abstract}


informasi berupa mencari tahu informasi terkait autisme dan memberi tahu informasi yang diperlukan anak.

Kata kunci: Dukungan sosial; autisme; orang tua memiliki lembaga pendidikan dan pelayanan anak berkebutuhan khusus (ABK)

Anak adalah anugerah terbesar yang diberikan oleh Allah SWT kepada orang tua, dimana pada mayoritas pasangan suami istri kehadiran anak menjadikan sebuah kesempurnaan dalam berumah tangga, dan tentunya yang diharapkan adalah anak yang terlahir sempurna dan utuh tanpa kekurangan satu apapun. Namun bagaimana jika yang terlahir adalah anak yang kurang sempurna dan memiliki kebutuhan khusus seperti anak dengan autisme. Kehadiran anak yang terlahir dengan autisme pada suatu keluarga dapat menjadi suatu hal yang mempengaruhi keadaan keluarga tersebut. Salah satunya adalah dalam mengurus dan mengasuh anak dengan autisme, Tentunya hal itu membuat orang tua akan lebih extra memberikan perhatiaanya.

Autisme sendiri merupakan gangguan yang mengakibatkan pertumbuhan anak tidak berkembang dengan optimal. Hal ini didukung dengan pernyataan Kenner yang mendiskripsikan bahwa gangguan autisme merupakan ketidakmampuan dalam menjalin hubungan interaksi dengan sesama, gangguan berbahasa, ecolalia, mutism, pembalikan kalimat serta adanya aktifitas bermain yang repetitif dan stereotif (Suteja, 2014). Yuwono juga mengatakan bahwa autisme merupakan gangguan perkembangan neuroboiologis yang sangat komplek dalam kehidupan, autisme sendiri meliputi gangguan pada aspek perilaku, interaksi sosial, komunikasi dan bahasa serta gangguan emosi dan persepsi sensori (Wijaksono, 2016).

Lingkungan anak itu sendiri tidak terlepas dari lingkungan keluarga yang mana orang tua berperan penting terhadap perkembangan anaknya agar berkembang secara optimal. Peneliti telah melakukan studi pendahuluan di salah satu Sekolah Dasar (SD) inklusi di Banjarmasin dan mendapatkan hasil wawancara bahwa terdapat salah satu orang tua dari anak dengan autisme yang cenderung sering menjalin hubungan komunikasi dengan wali kelas, guru pendamping maupun guru BK terkait informasi-informasi pembelajaran maupun kegiatan anaknya di sekolah. Tidak hanya itu, menurut informasi dari guru BK, orang tua dari 
anak dengan autisme itu pun membuat tempat terapi untuk anak berkebutuhan khusus di rumahnya, padahal orang tuanya tidak memiliki latar belakang sebagai terapis. Hal itu juga didukung oleh pernyataan tante dari anak dengan autisme tersebut yang mengatakan bahwa alasan dari orang tuanya membuat tempat terapi untuk anak berkebutuhan khusus adalah karena anaknya yang autisme. Di samping itu, menurut hasil wawancara dengan orang tua tersebut bahwa salah satu alasan mereka membuat lembaga pendidikan dan pelayanan anak berkebutuhan khusus (ABK) adalah karena melihat banyaknya biaya yang dihabiskan untuk terapi anak mereka, sehingga membuat mereka berpikir bagaimana jika orang yang kurang mampu juga mengalami hal yang sama seperti mereka hingga akhirnya mereka memutuskan untuk membuat lembaga pendidikan dan pelayanan anak berkebutuhan khusus (ABK) yang orientasinya bukan untuk profit namun membantu orang tua yang kurang mampu agar anaknya bisa di terapi. Artinya orang tua dari anak dengan autisme tersebut memberikan dukungan yang optimal, sehingga mereka membuat lembaga pendidikan dan pelayanan anak berkebutuhan khusus $(\mathrm{ABK})$ di rumah mereka sendiri. Sedangkan pada kasus lain di Indonesia tepatnya di Kabupaten Nunukan provinsi Kalimantan Utara terdapat kasus yang bertolak belakang, yaitu orang tua menelantarkan anaknya yang memiliki keterbelakangan mental sehingga anak tersebut harus tinggal di gudang barang bagian sosial dinas tenaga kerja transmigrasi dan sosial Kabupaten Nunukan karena dinas sosial kesulitan mencari data orang tua anak tersebut (Kompas, 2014).

Bedasarkan dua kasus tersebut terdapat perbedaan yang sangat signifikan yang mana pada kasus yang terjadi di Kabupaten Nunukan yaitu orang tua yang menelantarkan anaknya dan pada kasus yang ditemui oleh peneliti saat studi pendahuluan ialah orang tua yang sangat peduli terhadap anaknya yang berkebutuhan khusus sehingga berupaya memberikan dukungan moril maupun materil kepada anaknya Maka dari itu dukungan sosial orang tua dinilai memiliki fungsi yang sangat berpengaruh pada kehidupan anak dengan autisme. Sarafino menjelaskan bahwa dukungan sosial itu mengacu pada kenyamanan, kepedulian, penghargaan atau bantuan yang dirasakan seseorang yang diterima dari orang lain atau kelompok sehingga menumbuhkan rasa nyaman, dicintai, dihargai dan dibantu (Oktaviana, 2016). Yusuf dan Nurihsan juga berpendapat bahwasanya dukungan sosial seperti memberikan 
bantuan atau pertolongan kepada orang lain yang mengalami masalah, yang mana bantuan tersebut diberikan oleh orang yang memiliki hubungan dekat (Wijaksono, 2016). Dengan demikian peneliti tertarik untuk mengkaji lebih dalam terkait “Dukungan Sosial pada Anak dengan Autisme dari Orang Tua yang Memiliki Lembaga Pendidikan dan Pelayanan Anak Berkebutuhan Khusus (ABK)".

\section{Metode}

Pada penelitian ini peneliti memakai jenis penelitian studi kasus dengan menggunakan pendekatan kualitatif. Penelitian ini dilakukan di salah satu sekolah dasar (SD) inklusi yang ada di Banjarmasin dan dirumah subjek yang berada di jalan Sultan Adam, Kota Banjarmasin Provinsi Kalimantan Selatan. Adapun subjek penelitian ini yaitu orang tua terdiri dari ayah dan ibu mempunyai anak dengan autisme yang memiliki lembaga pendidikan dan pelayanan anak berkebutuhan khusus (ABK) dan objek pada penelitian ini ialah dukungan sosial orang tua terhadap anak dengan autisme yang meliputi dukungan emosional, dukungan penghargaan, dukungan instrumental dan dukungan informasi. Adapun teknik pengumpulan data yaitu menggunakan metode wawancara, observasi dan dokumentasi. Di samping itu, teknik analisis data yaitu dengan pengumpulan data, reduksi data, penyajian data dan penarikan kesimpulan.

\section{H a s i 1}

Berdasarkan hasil wawancara, diketahui bahwa JT adalah seorang ayah yang berusia 53 tahun dan $\mathrm{YH}$ adalah seorang ibu yang berusia 51 tahun. JT dan YH memiliki 3 orang anak diantaranya 2 perempuan dan 1 laki-laki yang mengalami autisme, JT bekerja di salah satu perusahaan publik yang bergerak di bidang logistik. Adapun YH pada awalnya bekerja di bidang jurnalistik di sebuah majalah sebagai editor in chief namun kemudian memutuskan untuk berhenti bekerja dan fokus untuk merawat anaknya yang mengalami autisme serta menangani tempat terapi yang ada di rumahnya yaitu lembaga pendidikan dan pelayanan Anak Berkebutuhan Khusus (ABK). Hari-hari JT dan YH banyak dihabiskan bersama anaknya yang autisme karena kedua anak mereka yang lain sudah tidak satu rumah dengan mereka 
sehingga hanya satu orang anak saja yang tinggal bersama mereka dan perlu diberikan perhatian lebih karena mengalami autisme. JT dan YH dikenal sebagai orang tua yang kompak dalam mengasuh anak mereka yang mengalami autisme, hal tersebut dapat dilihat dari bagaimana cara mereka membagi tugas dalam pengasuhan anak yang selalu saling support satu sama lain.

Pada awalnya respon pertamakali JT dan YH saat mengetahui anaknya mengalami autisme ialah terkejut dan tidak tahu harus berbuat apa namun hingga selang waktu berjalan rasa keterkejutan JT dan $\mathrm{YH}$ perlahan berkurang dan mulai untuk mencari tahu tentang autisme dari searching di internet maupun bertanya pada orang lain. Ada beberapa hal yang dilakukan oleh JT dan YH untuk membantu perkembangan S agar lebih optimal yang disebut sebagai bentuk dukungan sosial terhadap anaknya yang mengalami autisme yaitu dukungan emosional, dukungan penghargaan, dukungan instrumental dan dukunganan informasi. Adapun dukungan emosional yang diberikan oleh JT dan YH yaitu berupa kasih sayang, kepedulian dan perhatian, mendengarkan serta kepercayaan. Bentuk rasa kasih sayang yang diberikan JT dan YH ialah dengan berusaha menunjukkan sikap menyangi. Kemudian dalam bentuk kepedulian dan perhatian ditunjukkan JT dan YH dengan memberikan pengawasan ekstra penuh terhadap S. Dari segi mendengarkan, JT dan YH selalu mendengarkan apa yang dikatakan oleh S meskipun terkadang apa yang dikatakan oleh $\mathrm{S}$ tidak jelas, namun JT dan YH selalu mengiyakan. Di sisi lain, bentuk rasa kepercayaan yang ditunjukkan oleh JT dan YH yaitu dengan memberikan kebebasan atas apapun yang ingin dilakukan $S$, asalkan hal tersebut tidak membahayakan. Adapun bentuk dukungan penghargaan yang diberikan JT dan YH kepada $S$ yaitu dengan memberikan reward baik melalui ungkapan ataupun perbuatan seperti dipuji dan dipeluk.

Disamping itu, dukungan instrumental yang diberikan JT dan YH dapat berupa materi atau fasilitas seperti memberikan kebutuhan yang diperlukannya. Kemudian juga dukungan instrumental dapat berupa memberikan bantuan pekerjaan atau jasa seperti membantu $S$ dalam menyelesaikan tugas-tugasnya. Di lain hal, bentuk dukungan instrumental yang lainnya ialah berupa meluangkan waktu untuk menemani S. Adapun bentuk dukungan informasi yang diberikan JT dan $\mathrm{YH}$ yaitu dengan mencari tahu informasi yang berkaitan dengan autisme baik 
itu melalui internet maupun bertanya dengan teman dan juga memberi tahu informasi yang diperlukan anak dengan menjelaskan menggunakan bahasa yang mudah dipahami.

Adapun manfaat dari dukungan sosial yang diberikan terbagi menjadi beberapa macam diantaranya adalah manfaat dari dukungan emosional, dukungan penghargaan, dukungan instrumental dan dukungan informasi. Berdasarkan hasil wawancara yang dilakukan oleh peneliti, YH mengatakan bahwa manfaat dari dukungan emosional seperti menunjukkan kasih sayang dengan ungkapan maupun tindakan ialah agar terbentuknya kedekatan antara anak dan orang tua. Kemudian juga manfaat dari kepedulian dan perhatian yang berupa memberikan pengawasan lebih terhadap $S$ yaitu agar $S$ merasa aman dan nyaman sehingga tidak terjadi hal-hal yang tidak diinginkan. Di samping itu, manfaat dari memberikan kepercayaan pada S yang berupa memberikan kebebasan terhadap hal-hal yang diinginkannya, seperti ketika $S$ menolak untuk ditunggui di sekolah ialah agar anak bisa mandiri dan mengurangi rasa kecemasan orang tua. Di sisi lain, manfaat dari dukungan penghargaan yang berupa memberikan pujian atau pelukan atas hal positif yang dilakukan $\mathrm{S}$ ialah agar anak merasa dihargai atas usahanya.

Kemudian manfaat dari dukungan instrumental yang berupa memberikan materi atau fasilitas seperti laptop, handphone dan menyediakan wifi menurut YH manfaatnya ialah untuk mendukung minat dan keperluan anak. Di samping itu, manfaat dukungan instrumental berupa memberikan bantuan atau jasa seperti membantu mengerjakan tugas, mengajak anak untuk terapi pijit syaraf serta membuat tempat terapi adalah untuk memudahkan anak dalam mengerjakan tugas, anak menunjukkan perkembangan setelah di berikan terapi kemudian juga manfaat dari membuat tempat terapi adalah sebagai bentuk berbagi kepada orang tua yang juga mengalami hal yang sama yaitu memiliki anak berkebutuhan khusus. Di samping itu, menurut $\mathrm{YH}$ manfaat dari meluangkan waktu yang berupa selalu menemani $\mathrm{S}$ secara bergantian maupun bersama-sama ialah agar anak merasakan kehadiran orang tua dan tidak merasa sendirian.

Dari segi manfaat dukungan informasi yang berupa mencari tahu informasi yang dibutuhkan orang tua tentang autisme ialah agar mereka mengetahui apa yang dimaksudkan dengan autisme dan dapat mencari solusinya. Kemudian manfaat dari memberi tahu informasi 
yang dibutuhkan anak menurut $\mathrm{YH}$ yaitu agar anak mengetahui hal-hal yang belum dipahaminya.

\section{Pembahasan}

Berdasarkan data yang diperoleh, diketahui bahwa JT dan YH merasa terkejut dan bingung ketika pertama kali mengetahui anak mereka mengalami autisme karena menurut JT dan YH autisme tidak begitu dikenal seperti saat ini dan orang-orang dahulu beranggapan bahwa anak dengan autisme merupakan sebuah aib dalam suatu keluarga. Hal tersebut selaras dengan pernyataan yang dikemukakan oleh Mirza yaitu setiap orang tua ketika pertama kali mengetahui bahwa anaknya mengalami autisme akan timbul perasaan tidak percaya, marah, tidak dapat dapat menerima dengan beranggapan bahwa diagnosis tersebut salah, terkejut, panik, sedih, bingung dan sebagainya (Wijaksono, 2016). Kemudian dengan seiring berjalannya waktu rasa keterkejutan JT dan YH pun perlahan berkurang dan mereka juga mulai berusaha untuk mencari tahu hal-hal yang berkaitan dengan autisme, hingga akhirnya JT dan YH mulai memahami tentang bagaimana autisme itu dan tindakan apa yang selanjutnya dapat dilakukan untuk perkembangan anaknya. Oleh sebab itu menurut JT hal pertama yang harus dilakukannya adalah berdamai dengan keadaan dan menerima kenyataan bahwa memang kondisi anaknya seperti itu sehingga dengan penerimaan itu, JT dan YH dapat melangkah ke depan untuk melanjutkan apa yang harus dilakukan terhadap anak mereka. Hal ini sesuai dengan pernyataan Mirza Maulana bahwa salah satu hal yang bisa membantu keberhasilan dalam penanganan anak dengan autisme yaitu adalah kesiapan dari orang tua dalam menerima keadaan anaknya (Wijaksono, 2016). Adapun beberapa hal yang dilakukan oleh JT dan YH terhadap S untuk membantu perkembangannya agar lebih optimal bisa disebut sebagai bentuk dukungan sosial diantaranya adalah dukungan emosional, dukungan penghargaan, dukungan instrumental dan dukunganan informasi. Hal tersebut sesuai dengan pernyataan Levine, Basham dan Sarason menyebutkan komponen-komponen yang terdapat dalam dukungan sosial terbagi empat yaitu dukungan emosional, dukungan penghargaan, dukungan instrumental dan dukungan informasi (Komalasari, 2014). 
Dukungan emosional merupakan aspek yang pertama terdapat pada dukungan sosial. Adapun dukungan emosional yang diberikan oleh JT yaitu berupa kasih sayang seperti berusaha menunjukkan sikap menyayangi seperti memanggil $S$ dengan sebutan sayang serta memeluk S ketika tidur. Begitupun dengan YH ia juga berusaha untuk menunjukkan sikap menyayangi dengan menyiapkan makan untuk S bahkan terkadang juga disuapi, JT dan YH juga tidak terbiasa memarahi anak dengan berlebihan dan memberikan teguran dengan lembut agar anak memahami bahwa yang dilakukannya salah. Hal ini sejalan dengan pernyataan Weiss yang mengatakan bahwa terdapat beberapa komponen dalam dukungan sosial diantaranya adalah dukungan emosional yang dapat berupa pengekspresian dari kasih sayang dan cinta yang diterima individu (Maslihah, 2011). Sehingga bentuk kasih sayang dan cinta diekspresikan JT dan YH dengan berusaha menunjukkan sikap menyayangi melalui ungkapan maupun tindakan seperti memeluk, memanggil dengan sebutan sayang, menyiapkan makan untuk S, dan memberikan teguran dengan lembut agar anak memahami kesalahannya.

Kemudian bentuk dukungan emosional berikutnya berupa kepedulian dan perhatian, yang mana JT dan YH melakukan pengawasan lebih terhadap S, JT juga selalu menanyakan kegiatan apa saja yang dilakukan S di sekolah ketika pulang sekolah, membawa S jalan-jalan agar dapat berinteraksi dengan lingkungan, Begitu juga dengan $\mathrm{YH}$, ia berusaha memberikan perhatian lebih terhadap $S$ dengan menuntun $S$ ketika berjalan, mengantar $S$ masuk kelas dan menunggui S disekolah ketika S sedang sakit. Tidak hanya itu JT dan YH juga cepat tanggap dalam mengatasi permasalahan yang dialami $S$, seperti ketika S diganggu oleh orang lain maka JT dan YH langsung mengambil tindakan tegas untuk mendatangi sekolah anak tersebut dan melaporkan kepada pihak sekolah. Hal tersebut selaras dengan pernyataan Sarason, Levine dan Basham bahwa dukungan emosional dapat berupa kepedulian dan perhatian terhadap orang yang bersangkutan (Komalasari, 2014). Di samping itu, menurut Sarafino kepedulian dan perhatian merupakan aspek yang ada dalam dukungan emosional yang mana kepedulian dapat diartikan dengan sikap dan tindakan menghargai apa yang dibutuhkan oleh orang lain, yang sikap ini merupakan tindakan langsung yang diberikan pada orang yang mengalami gangguan. Adapun perhatian dapat diartikan sebagai sikap positif untuk memfokuskan diri pada orang lain, sikap ini ditunjukkan dengan perhatian yang diberikan kepada orang yang 
mengalaminya (Sundari, 2015). Sehingga bentuk kepedulian dan perhatian JT dan YH ditunjukan dengan memberikan pengawasan kepada anak, menanyakan kegiatan anak, mengusahakan anak untuk berinteraksi dengan lingkungan sekitar, dan cepat tanggap ketika anak mengalami masalah.

Adapun bentuk dukungan emosional selanjutnya adalah berupa mendengarkan, JT dan YH dinilai oleh keluarganya selalu mendengarkan apa yang dikatakan oleh S meskipun terkadang apa yang dikatakan oleh $\mathrm{S}$ tidak begitu jelas tetapi JT dan YH selalu memberikan respon. Hal itu, sejalan dengan pernyataan Sarafino bahwa dukungan emosional itu dapat meliputi perilaku bersedia mendengarkan orang lain (Kusrini \& Nanik, 2014). Di lain hal, bentuk dukungan emosional yang lain yaitu berupa memberikan kepercayaan, JT dan YH berusaha untuk memberikan kepercayaan atas apa yang di lakukan oleh S seperti ketika JT mengajak $S$ untuk shalat berjamaah namun $S$ memilih ingin shalat sendiri, maka JT tidak memaksakan kehendaknya dan percaya bahwa S akan shalat sendiri. Tidak hanya itu menurut YH, S juga sudah tidak ditunggui lagi di sekolah bahkan terkadang $S$ menolak ketika ditawari untuk di antar ke kelas dan beralasan bisa sendiri. JT juga memberikan kebebasan atas apapun hal yang ingin dilakukan oleh S asal tidak membahayakan. Artinya JT dan YH memberikan kepercayaan mereka atas hal apapun dilakukan S. Adapun menurut Johnson kepercayaan merupakan dasar dalam membangun dan mempertahankan hubungan interpersonal, Henslin juga memandang kepercayaan sebagai harapan dan kepercayaan individu terhadap reliabitas orang lain (Risandy, 2018). Berdasarkan dari pemaparan di atas dapat disimpulkan bahwa bentuk dukungan emosional dapat berupa memberikan kasih sayang, memberikan kepedulian dan perhatian, berusaha mendengarkan dan memberikan kepercayaan.

Dukungan penghargaan adalah aspek kedua yang terdapat dalam dukungan sosial, adapun bentuk dukungan penghargaan yang diberikan JT dan YH kepada S yaitu dengan memberikan reward atas hal positif yang dilakukannya baik itu melalui ungkapan ataupun perbuatan seperti dipuji dengan kata-kata yang positif dan dipeluk sebagai tanda penghargaan. Hal tersebut selaras dengan pernyataan Sarafino yang mengatakan bahwa dukungan penghargaan yang diberikan dapat berupa reward atau penghargaan yang positif (Oktafiana, 
2016). Sehingga bentuk penghargaan yang diberikan JT dan YH terhadap S yaitu dapat berupa memberikan reward atas hal positif yang dilakukan dengan pujian maupun pelukan.

Dukungan instrumental merupakan aspek yang ketiga dalam dukungan sosial, adapun dukungan instrumental yang diberikan JT dan YH yaitu berupa memberikan barang elektronik seperti handphone, laptop dan menyediakan wifi di rumah. Di samping itu, JT dan YH juga memasukkan $S$ ke sekolah inklusi yang sesuai dengan kebutuhannya serta memberikan guru pendamping di sekolah, selain itu, mereka juga memanggil terapis pribadi untuk menerapi $\mathrm{S}$ di rumah agar perkembangannya lebih optimal dan membawa $S$ ke tempat pijit saraf untuk menstimulasi kemampuan bicaranya. Tidak hanya itu, JT dan YH juga membuat lembaga pendidikan dan pelayanan anak berkebutuhan khusus dirumahnya. Dari pemaparan tersebut selaras dengan pernyataan Sarason, Levine dan Basham bahwa dukungan instrumental mencangkup bantuan finansial baik itu berupa benda maupun fasilitas yang diberikan (Komalasari, 2014). Sehingga bentuk dukungan instrumental yang mencangkup bantuan finansial maupun fasilitas yang diberikan JT dan $\mathrm{YH}$ yaitu berupa menyediakan fasilitas yang dibutuhkan anak seperti memberikan handpone dan lapotop, menyediakan akses wifi dirumah, menyekolahkan anak di sekolah inklusi yang sesuai dengan kebutuhan, memberikan guru pendamping di sekolah, memberikan terapis pribadi di rumah serta membuat lembaga pendidikan dan pelayanan anak berkebutuhan khusus (ABK) di rumah.

Di lain hal, bentuk dukungan intrumental yang lainnya adalah berupa memberikan bantuan pekerjaan atau jasa, adapun bantuk bantuan yang diberikan JT dan YH adalah berupa membantu $S$ dalam mengerjakan tugas sekolah dengan membagi mata pelajaran yang akan di ajarkan kepada S, kemudian JT dan YH juga selalu menemani S untuk terapi pijit saraf dari umur 2 tahun hingga akhirnya dapat berbicara di umur 7 tahun bahkan hal tersebut masih dilakukan sampai sekarang meskipun tidak sesering dahulu. Tidak hanya itu, bantuan yang lainnya juga berupa mengantar dan menjemput $S$ di sekolah, cepat tanggap ketika $S$ mengalami masalah di sekolah. YH juga sering menjalin komunikasi dengan guru S, hal tersebut dilakukan YH untuk mempermudah proses belajar S di sekolah seperti menanyakan tugas atau pekerjaan rumah yang diberikan guru, ia juga selalu datang ke sekolah di waktu istirahat hanya sekedar untuk menemani S makan siang lalu kemudian pulang lagi. Dari beberapa hal tersebut sejalan 
dengan pernyataan Sarason, Levine dan Basham yang mengatakan bahwa dukungan instrumental dapat berupa bantuan langsung dalam mengerjakan tugas ataupun pekerjaan tertentu (Komalasari, 2014). Sehingga bentuk dukungan instrumental yang mencangkup bantuan pekerjaan atau jasa yang diberikan JT dan YH yaitu berupa membantu dalam mengerjakan tugas sekolah, menemani anak untuk terapi pijitt saraf, mengantar dan jemput anak sekolah, menemani anak makan siang di sekolah, aktif menjalin komunikasi dengan guru dan cepat tanggap ketika anak mengalami masalah.

Kemudian bentuk dukungan instrumental yang lainnya adalah meluangkan waktu, menurut JT dan YH mereka selalu meluangkan waktu untuk menemani S, baik itu hanya di rumah maupun keluar rumah Dalam hal ini, YH lebih sering menghabiskan waktu dengan S hal tersebut di karenakan $\mathrm{YH}$ memutuskan untuk berhenti bekerja dan ingin fokus untuk merawat S, Meskipun demikian JT juga selalu meluangkan waktu untuk menemani S di selasela kesibukan bekerja seperti mangajak makan siang bersama, menemani S setelah pulang bekerja bahkan mengajak S untuk jalan-jalan di hari weekend. Begitupun ketika JT dan YH dipanggil ke sekolah untuk konseling orang tua, mereka langsung datang dan meluangkan waktu untuk mengikuti konseling orang tua. Hal ini selaras dengan pendapat Cutrona \& Gardner yang mengatakan dukungan instrumental itu dapat berupa meluangkan waktu (Dianto, 2017). Sehingga bentuk dari meluangkan waktu yang diberikan JT dan YH dapat berupa menemani anak dalam kondisi apapun, mengajak anak untuk jalan-jalan, dan menghabiskan waktu bersama anak. Jadi berdasarkan beberapa pemaparan yang telah disebutkan dapat disimpulkan bahwa dukungan instrumental dapat berupa memberikan materi atau fasilitas, membantu pekerjaan atau jasa dan meluangkan waktu. Hal tersebut selaras dengan pernyataan Sarfino bahwa dukungan instrumental merupakan bantuan langsung seperti uang, waktu dan tenaga melalui tindakan yang dapat membantu seseorang. House juga berpendapat bahwa dukungan instrumental itu berupa berbagai macam bantuan langsung atau nyata, uang, tenaga atau tindakan dan waktu (Setyaningrum, 2015).

Dukungan informasi merupakan aspek terakhir yang ada pada dukungan sosial, adapun bentuk dukungan informasi dari JT dan YH yaitu mencari tahu informasi yang berkaitan dengan autisme dan memberi tahu informasi yang dibutuhkan anak, adapun bentuk 
mencari tahu informasi yang dibutuhkan terkait dengan autisme yaitu dengan mencari informasi melalui internet atau bertanya dengan teman yang mengerti tentang autisme. JT juga mengatakan bahwa ia memperhatikan bagaimana cara terapis memperlakukan $S$ dan pelanpelan mempelajarinya untuk jadi bahan acuan dalam memperlakukan S. Disamping itu bentuk memberi tahu informasi yang dibutuhkan anak yaitu dengan menjelaskan kepada $S$ jika ada sesuatu hal yang tidak diketahuinya seperti menegur apabila $S$ melakukan kesalahan dan memberikan contoh bagaimana yang benar, serta menjelaskan hal-hal yang ditanyakan anak dengan menggunakan bahasa yang mudah dipahami anak. Hal tersebut merujuk dari pendapat Sarafino yang mengatakan bahwa dukungan informasi itu dapat berupa saran, pengarahan serta umpan balik dalam memecahkan persoalan (Kumalasari \& Ahyani, 2012). Kemudian Taylor juga mengatakan bahwa dukungan informatif itu adalah memberikan informasi yang dibutuhkan (Setyaningrum, 2015). Sehingga bentuk dukungan informasi yang diberikan JT dan $\mathrm{YH}$ yaitu berupa mencari tahu informasi yang berkaitan dengan autisme dan memberi tahu informasi yang dibutuhkan anak.

Berdasarkan hasil wawancara yang telah dilakukan, peneliti mendapatkan informasi terkait dengan manfaat dari dukungan sosial yang diberikan oleh JT dan YH terhadap anaknya yang mengalami autisme. Adapun manfaat dari dukungan sosial terbagi menjadi empat yang pertama adalah manfaat dari dukungan emosional yang mana berdasarkan hasil wawancara, YH berpendapat bahwa manfaat dari dukungan emosional yang diberikan yaitu berupa menunjukkan kasih sayang dengan ungkapan maupun tindakan seperti memanggil dengan sebutan sayang dan memeluk adalah agar terbentuknya kedekatan antara orang tua dan anak, karena menurut $\mathrm{YH}$, sebelumnya S tidak suka disentuh secara fisik sehingga membuat JT dan YH selalu berusaha untuk memeluk S hingga akhirnya S terbiasa, dan menurut $\mathrm{YH}$ dengan terbiasanya S dipeluk maka akan menumbuhkan kedekatan antara anak dan orang tua. Di samping itu, manfaat dari dukungan emosional yang berupa memberikan kepedulian dan perhatian adalah agar anak merasa aman dan nyaman dan tidak terjadi hal-hal yang tidak diinginkan. Tidak hanya itu, menurut penjelasan $\mathrm{YH}$ manfaat dari dukungan emosional yang berupa memberikan kepercayaan terhadap $S$ atas hal-hal yang dilakukannya adalah agar melatih anak untuk mandiri dan mengurangi rasa kecemasan orang tua. Jadi berdasarkan 
pemaparan di atas dapat disimpulkan bahwa manfaat dari memberikan dukungan emosional adalah agar terbentuknya kedekatan antara orang tua dan anak, membuat anak merasa aman dan nyaman, melatih anak untuk mandiri serta mengurangi rasa kecemasan orang tua. Hal tersebut selaras dengan pernyataan Sarafino bahwa pemberian dukungan emosional dapat memberikan dampak positif sebagai sarana pelepasan emosi, mengurangi kecemasan, membuat individu merasa nyaman, tentram, diperhatikan serta dicintai (Juniastira, 2018). Di samping itu, Weiss juga mengatakan hal serupa bahwa dukungan emosional yang berupa pengekspresian kasih sayang dan cinta dapat memberikan rasa aman kepada orang yang menerima serta menumbuhkan kedekatan dan keintiman (Maslihah, 2011). Sehingga dengan adanya dukungan emosional tersebut anak dapat merasakan bentuk kasih dari orang tuanya.

Kemudian yang kedua yaitu manfaat dari dukungan penghargaan yang mana menurut YH ketika S melakukan hal positif maka JT dan YH memberikan reward dengan memuji menggunakan kata-kata positif ataupun memeluknya, hal tersebut memberikan manfaat agar anak merasa dihargai atas usahanya. Hal itu didukung dengan pernyataan Sarafino bahwa memberikan dukungan penghargaan dapat memberikan dampak dalam menciptakan rasa berharga, kompeten dan bernilai (Wijaksono, 2016). Sehingga dengan adanya dukungan penghargaan tersebut anak dapat merasa dihargai oleh orang tuanya.

Adapun manfaat yang ke tiga yaitu manfaat dari dukungan instrumental yang berupa memberikan materi atau fasilitas seperti laptop, handphone, wifi dan kebutuhan lainnya menurut $\mathrm{YH}$ manfaatnya ialah untuk mendukung minat dan keperluan anak kerena $\mathrm{S}$ sangat menyukai hal-hal yang berkaitan dengan laptop bahkan S bisa menggambar menggunakan aplikasi yang ada di laptop tanpa ada yang mengajarinya, begitupun dengan handphone $S$ juga sangat tertarik untuk mencari informasi-informasi yang ada di internet melalui searching di google. Bahkan YH juga pernah untuk mengarahkan S ke dunia musik namun $\mathrm{S}$ tidak tertarik, hingga akhirnya JT dan YH memutuskan untuk mendukung apa yang jadi passion anaknya dan menyediakan apa yang menjadi keperluannya. Kemudian juga menurut $\mathrm{YH}$ manfaat dari dukungan instrumental yang berupa memberikan bantuan atau jasa seperti membantu mengerjakan tugas, mengajak anak untuk terapi pijit syaraf serta membuat tempat terapi ialah untuk memudahkan anak dalam menyelesaikan tugas, anak menunjukkan perkembangan 
setelah di berikan terapi kemudian juga manfaat dari membuat tempat terapi adalah sebagai bentuk berbagi kepada orang tua yang juga mengalami hal yang sama yaitu memiliki anak berkebutuhan khusus. Di samping itu, manfaat dari meluangkan waktu untuk anak menurut YH ialah agar anak merasakan kehadiran orang tua. Jadi berdasarkan penjelasan tersebut dapat disimpulkan bahwa manfaat dukungan instrumental adalah untuk mendukung minat dan keperluan anak, untuk membantu anak dalam mengerjakan tugas-tugasnya, kemudian juga agar anak menunjukkan perkembangannya, dan sebagai bentuk berbagi kepada orang tua yang juga memiliki anak berkebutuhan khusus serta agar anak dapat merasakan kehadiran orang tua. Hal tersebut juga didukung oleh pernyataan Sarafino bahwa manfaat dukungan instumental ialah dapat mengurangi beban atau kesulitan yang dihadapi.(Susilowati, 2007). Sehingga dengan adanya dukungan instrumental tersebut anak dapat merasa terb antu dalam menghadapi kesulitan yang dialaminya.

Kemudian manfaat yang terakhir yaitu adalah manfaat dukungan informasi yang berupa mencari tahu informasi yang dibutuhkan orang tua tentang autisme yang mana menurut hasil wawancara YH mengatakan bahwa manfaatnya adalah agar mereka mengetahui apa yang dimaksudkan dengan autisme dan dapat mencari solusinya. Kemudian manfaat dari dukungan informasi yang berupa memberi tahu informasi yang dibutuhkan anak yaitu agar anak mengetahui hal-hal yang belum dipahaminya. Jadi dapat disimpulkan bahwa manfaat dukungan informasi adalah agar orang tua mengetahui apa yang dimaksudkan dengan autisme dan dapat mencari solusinya serta agar anak juga dapat mengetahui hal-hal yang belum dipahaminya. Hal tersebut sesuai dengan pernyataan Sarafino bahwa pemberian dukungan informasi dapat membantu seseorang dalam mencari jalan keluar dari kesulitan yang dihadapi dan memperoleh solusi dari kesulitan (Susilowati, 2007). Sehingga dengan adanya dukungan informasi tersebut orang tua dan anak dapat memperoleh solusi dari kesulitan yang dihadapi.

\section{Kesimpulan}

Dari hasil penelitian yang telah dilakukan dapat disimpulkan bahwa bentuk dukungan sosial pada anak dengan autisme dari orang tua yang memiliki lembaga pendidikan dan pelayan Anak Berkebutuhan Khusus (ABK) terbagi dari beberapa bentuk dukungan di 
antaranya ialah dukungan emosional, dukungan penghargaan, dukungan instrumental dan dukungan informasi. Adapun bentuk dukungan emosional ialah berupa memberikan kasih sayang, memberikan kepedulian dan perhatian, bersedia mendengarkan anak dan memberikan kepercayaan. Kemudian dukungan penghargaan yang diberikan oleh orang tua adalah berupa memberikan reward atas hal positif yang dilakukan anak. Adapun bentuk dukungan instrumental adalah memberikan dukungan berupa bantuan materi atau fasilitas, memberikan dukungan berupa bantuan pekerjaan atau jasa dan meluangkan waktu untuk menemani anak. Begitupun dengan bentuk dukungan informasi yang diberikan adalah berupa mencari tahu informasi terkait autisme dan memberi tahu informasi yang diperlukan anak.

Adapun manfaat dari dukungan emosional yang berupa membentuk kedekatan antara anak dan orang tua, membuat anak merasa aman dan nyaman, melatih anak untuk mandiri dan mengurangi kecemasan orang tua. Kemudian manfaat dukungan penghargaan ialah agar merasa dihargai atas usahanya, di samping itu, manfaat dari dukungan instrumental adalah sebagai bentuk dukungan terhadap minat dan keperluan anak, memudahkan anak dalam menyelesaikan tugas, anak menunjukkan perkembangannya, dan sebagai bentuk berbagi kepada orang tua yang juga memiliki anak berkebutuhan khusus, serta membuat anak merasakan kehadiran orang tua. Begitupun dengan manfaat dari dukungan informasi adalah agar orang tua mengetahui apa yang dimaksudkan dengan autisme dan dapat mencari solusinya serta membantu anak agar mengetahui hal-hal yang belum dipahaminya.

\section{Saran}

Disarankan untuk subjek penelitian agar terus menjalankan hal-hal yang telah dilakukan terhadap anak agar dapat membantu dalam mengoptimalkan perkembangan anak seperti memberikan fasilitas terapi di rumah, membawa anak ke tempat pijit saraf serta membantu anak dalam proses belajar. Selain itu, diharapkan juga bagi orang tua untuk tetap konsisten pada pola asuh yang telah diberikan kepada anak selama ini. Selalu bersyukur dan berpikir positif atas hal-hal yang telah terjadi sehingga anak dapat merasakan energi positif yang diberikan orang tua. Disamping itu, orang tua juga disarankan untuk mendukung apa yang menjadi minat anak agar dapat berkembang dengan optimal. Kemudian untuk peneliti 
selanjutnya diharapkan agar bisa melakukan penelitian dalam ruang lingkup yang lebih besar, agar hasil yang didapatkan lebih beragam.

\section{Referensi}

Dianto, M. (2017). Profil Dukungan Sosial Orang Tua Siswa di SMP Negeri Kecamatan Batang Kapas Pesisir Selatan. Jurnal Conseling care,1(1).

Fani Kumalasari, \& Latifah Nur Ahyani. (2012). Hubungan antara Dukungan Sosial dengan Penyesuaian Diri Remaja di Panti Asuhan. Jurnal Psikologi Pitutur,1 (1).

Juniastira, S. (2018). Hubungan antara Dukungan Sosial dan Kualitas Hidup pada Pasien Stroke. [Skripsi] Universitas Islam Indonesia Yogyakarta.

Komalasari, S. (2014). Pelatihan Dukungan Sosial untuk Meningkatkan Kualitas Interaksi Atasan Bawahan [Skripsi]. Universitas Islam Indonesia Yogyakarta.

Kompas. (2014). Ditelatarkan oran tua, nasib aldy berakhir digudang. https://regional. kompas.com/read/2014/10/15/01061451/Ditelantarkan.Orang.Tua.Nasib.Aldy.Berakhir.di .Gudang?page $=$ all

Kusrini, W., \& Nanik, P. (2014). Hubungan Dukungan Sosial dan Kepercayaan DIri dengan Prestasi Bahasa Inggris Siswa Kelas VIII SMP Negeri 6 Boyolali. Jurnal Penelitian Humaniora, 15(2).

Maslihah, S. (2011). Studi Tentang Hubungan Dukungan Sosial, Penyesuaian Sosial di Lingkungan Sekolah dan Prestasi Akademik Siswa SMPIT Assyfa Boarding School Jawa Barat. Jurnal Psikologi Undip 10(2).

Oktafiana, R. (2016). Dukungan Sosial keluarga, Sekolah dan Masyarakat Bagi Kemandirian Ekonomi Difabel Grahita [Skripsi]. Universitas Sunan Kalijaga Yogyakarta.

Risandy, A. (2018). Pengaruh Kepercayaan dan Dukungan Keluarga terhadap Kebahagiaan Pernikahan pada Mahasiswa yang Menikah Muda [Skripsi]. UIN Syarif Hidayatullah Jakarta.

Setyaningrum, A. (2015). Pengaruh Dukungan Sosial OrangTua Terhadap Motivasi Berprestasi Siswa Kelas V Sekolah Dasar di Gugus Hasanudin Kabupaten Cilacap Tahun Ajaran 2014/2015 [Skripsi]. Universitas Negeri Yogyakarta.

Sundari, L. (2015). Hubungan Antara Dukungan Emosional Teman Sebaya dengan Motivasi Berprestasi pada Atlet Hockey di Kabupaten Kendal [Skripsi]. Universitas Kristen Satya Kencana.

Susilowati, A. T. (2007). Hubungan antara Dukungan Sosial dan Tingkat Stres Orang Tua dari Anak Autis [Skripsi]. Universitas Sanata Dharma.

Suteja, J. (2014). Bentuk dan Metode Terapi Terhadap Anak Autisme Akibat Bentukan Perilaku Sosial. Jurnal Edueksos 3(1)

Wijaksono, R. (2016). Studi Kasus tentang Pengaruh Dukungan Sosial dalam Membangun Penerimaan Orangtua terhadap Anaknya yang Autis [Skripsi]. Universitas Negeri Yogyakarta. 


\begin{tabular}{|l|l|l|l|l|}
\hline Submit & Review & Revisi & Diterima & Publish \\
\hline $10-12-2020$ & - & - & $30-03-2021$ & $22-04-2021$ \\
\hline
\end{tabular}

Syamya Noor Hasanah, Irfan Noor dan Shanty Komalasari

Program Studi Psikologi Islam

Fakultas Ushuluddin dan Humaniora

Universitas Islam Negeri (UIN) Antasari Banjarmasin

Email : Syamya2113@gmail.com 